\title{
MHRA

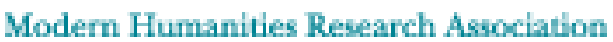

Cultural Intersections: The American Hard-Boiled Detective Novel and Early French roman

noir

Author(s): Claire Gorrara

Source: The Modern Language Review, Vol. 98, No. 3 (Jul., 2003), pp. 590-601

Published by: Modern Humanities Research Association

Stable URL: http://www.jstor.org/stable/3738287

Accessed: 19/02/2014 07:13

Your use of the JSTOR archive indicates your acceptance of the Terms \& Conditions of Use, available at

http://www.jstor.org/page/info/about/policies/terms.jsp

JSTOR is a not-for-profit service that helps scholars, researchers, and students discover, use, and build upon a wide range of content in a trusted digital archive. We use information technology and tools to increase productivity and facilitate new forms of scholarship. For more information about JSTOR, please contact support@jstor.org.

Modern Humanities Research Association is collaborating with JSTOR to digitize, preserve and extend access to The Modern Language Review. 


\section{CULTURAL INTERSECTIONS: THE AMERICAN HARD-BOILED DETECTIVE NOVEL AND EARLY FRENCH ROMAN NOIR}

In his study of French intellectuals and their relationship to America during the twentieth century, Jean-Philippe Mathy points to the predominance of a 'paradigm of discontinuity', a set of textual constructs which posit America as a site of rupture with the cultural, political, economic, and social structures of Europe. ${ }^{\mathrm{I}}$ For Mathy, such a perception has been articulated mainly in terms of a pervasive anti-Americanism centred on two phenomena: technological production and mass consumption. By charting the shifting collective and individual manifestations of such sentiments in French literary and philosophical traditions, Mathy comes to establish a number of privileged tropes. They present American society and culture as anti-intellectual, spiritually void, and predicated on rampant consumerism.

However, for Mathy, such anti-American discourses form part of a multiform 'rhetoric of America' that equally incorporates a counter-mythology of fascination with the innovation and the dynamism of American modernity. Such pro-American sentiments were to find one of their high points in postLiberation France. This was a time when American culture, banned during the German occupation, was feverishly sought as offering new departures in film, literature, and music. It represented a fantastic future of mythical proportions for French intellectual figures, such as Simone de Beauvoir when she recorded her impressions of the period in her autobiographical account of those years, La Force des choses:

Ça signifiait tant de choses, l'Amérique! Et d'abord, l'inaccessible; jazz, cinéma, littérature, elle avait nourri notre jeunesse mais aussi elle avait éte un grand mythe: un mythe ne se laisse pas toucher. [...] L'Amérique, c'était aussi la terre d'où nous était venue la délivrance; c'était l'avenir en marche; c'était l'abondance et l'infini des horizons; c'était un tohu-bohu d'images légendaires: à penser qu'on pouvait les voir de ses yeux, on avait la tête tournée. ${ }^{2}$

However, Beauvoir's first trip to America in 1947, published in 1948 as L'Amérique au jour le jour, was to demonstrate a more ambivalent image of the country as a kind of 'fascinated repulsion' tempered her uncritical expectations. For if Beauvoir's travelogue delighted in American cinema, monumental landscapes, and the bright lights of New York, it also probed the underside of the American dream; the slaughterhouses of Chicago, poverty and deprivation in the Bowery, and, most importantly, racial prejudice and persecution.

Beauvoir's first-hand experience of America in her travelogue is clearly medi-

I would like to thank the British Academy for funding a research trip to Paris to visit the Bibliothèque des littératures policières, where I was able to consult much of the primary material for this article.

' Jean-Philippe Mathy, Extrême-Occident: French Intellectuals and America (Chicago: University of Chicago Press, 1993). See too Richard Kuisel, Seducing the French: The Dilemma of Americanization (Berkeley: University of California Press, 1993), for an insightful analysis of how the French have constructed and understood America over the twentieth century.

${ }^{2}$ Simone de Beauvoir, La Force des choses (Paris: Gallimard, 1963), p. 28. 
ated through a complex set of commonplaces and cultural references and draws on a long tradition of French narrative representations of America. On the one hand, there is Beauvoir's sense of cultural superiority as part of a European intellectual élite, and on the other, anxiety and self-doubt about a Europe and a France perceived as out of step with the forward-looking New World. Yet Beauvoir's travelogue not only engages with past representations of America, it is also resolutely of its time, the late r 940 s and early I950s. These were the years when American economic and cultural imperialism forced French writers and intellectuals to ponder their own country's place in a new Cold War world order.

This article will discuss the years immediately following the Liberation and explore popular representations of America in the embryonic genre of the French roman noir. Exported en masse to France in the immediate aftermath of war, the American novels of Raymond Chandler and Dashiell Hammett first became widely available in translation to French readers through the Série noire, founded by Marcel Duhamel in I 945. This hard-boiled detective novel elicited contradictory responses from critics in the late r940s as they debated the influence of American literature on contemporary French fiction. However, despite the reservations of some, this American literary model was taken up and adapted to suit a post-war French readership by detective fiction writers, such as Terry Stewart and John Amila, two Frenchmen writing under Americanized pseudonyms. Their first novels in the Série noire are extremely critical of American culture and society, projecting an image of a nation in crisis. At a time of cultural exchanges, of transatlantic encounters, and enthusiasm for all things American, the American hard-boiled detective story would be appropriated by a number of French writers, like Stewart and Amila, for a transposed critique of the recent past and their anxieties about the future.

The most important writer associated with the first American hard-boiled detective stories is Dashiell Hammett, whose writing career began in I 923 with short stories published in the pulp magazine Black Mask, and included acclaimed masterpieces such as Red Harvest (1929). A former private detective, Hammett represented a new generation of writers who had more than a passing acquaintance with the darker side of American society. The specific historical context in which Hammett wrote presented him with a vision of society on the verge of breakdown: Prohibition, the Depression, the Wall Street crash, the rise of a gangster culture, racial tension and violence, rural poverty, and corruption at all levels of policing and government. For those American novelists like Hammett returning from the battlefields of the First World War, the American Dream had failed to materialize, leaving a bitter aftertaste of what could have been.

The innovation of Hammett's work was less in the formula of his novels, the world-weary private eye and his serial investigations, than in the atmosphere and style of his writing. Raymond Chandler, in his now famous essay 'The Simple Art of Murder', credits Hammett with taking 'murder out of the Venetian vase and dropping it into the alley'. ${ }^{3}$ It was Hammett who wrote what

\footnotetext{
3 Raymond Chandler, 'The Simple Art of Murder', in Pearls are a Nuisance (Harmondsworth: Penguin, I 966), pp. I8 1-99 (p. I 94).
} 


\section{The American Detective Novel and the French 'Roman noir'}

Chandler called 'realistic mystery fiction', ${ }^{4}$ set in an urban metropolis which had nothing to do with the intellectual puzzle and refined location of the English country-house mystery, so much in vogue during the interwar period. Instead, Hammett's narratives presented an urban jungle where social, political, and economic interests conspired to defeat the small man, where organized crime was routinely found pulling the strings of elected city officials, and where each murder was the tip of the iceberg, destroying the fragile illusion that the rule of law sustained the social order. The Maltese Falcon (1929), one of Hammett's best-known novels, combines these elements in its depiction of a gang of treacherous thieves and rogues, all in pursuit of a famed treasure, the Maltese Falcon. Narrated from the jaundiced perspective of private eye Sam Spade, the novel plunges the reader into an unpredictable and violent social space where greed and desire prompt the main characters into a series of murders, including that of Spade's partner, Miles Archer. Eventually discovered to be not a treasure after all but a worthless fake, the Maltese Falcon itself represents the illusory promise of wealth and power associated with the American Dream and the harsh realities of life in urban America. It was this search for a lost treasure and the human foibles it revealed that was to act as the template for the first truly French roman noir: I20, rue de la Gare (1943) written by Léo Malet during another dark period in history, les années noires of the Occupation. ${ }^{5}$

Later critics of the hard-boiled genre were to pinpoint more precisely the forms and structures that differentiated such a genre of detective fiction from other types, such as the murder mystery or the psychological thriller. Tzvetan Todorov's 'A Typology of Detective Fiction' provides a fully functioning structuralist analysis of what he names the série noire in deference to the French model. ${ }^{6}$ Todorov notes that the hard-boiled form is less wedded to the classic distinction between the story of the crime and the story of the investigation common to the murder-mystery novels of writers such as Agatha Christie and Ellery Queen. In their novels, the detecting figure acts as an omniscient eye, able to survey, judge, and logically dissect past crimes. In contrast, the hardboiled model begins by pitching the detecting figure into the midst of events as crimes and their investigation hasten one upon the other, often difficult to untangle and comprehend. With the forward momentum of the narrative preventing any clear-cut comprehension of events, the hard-boiled model aligns the reader with the involved viewpoint of the detective-hero and enables her/ him to share this figure's heady sense of disorientation and malaise.

In more recent years, the hard-boiled model has attracted the attention of cultural critics such as Lee Horsley, who has interpreted the genre as a narrative of our times, 'a popular expression of modernist pessimism'.7 Horsley fleshes out and extends Todorov's typology to read the noir model as an organizing principle for a whole range of concepts and genres that far exceeds the annals

4 Ibid.

5 For a discussion of the cultural hybridity of this early French roman noir, see my 'Malheurs et Ténèbres: Narratives of Social Disorder in Léo Malet's I2O, rue de la Gare', French Cultural Studies, 12 (October 2001 ), $271-83$.

${ }^{6}$ In The Poetics of Prose, trans. Richard Howard (Oxford: Blackwell, 1977), 42-52.

7 The 'Noir' Thriller (Basingstoke: Palgrave, 200 I), p. I. 
of crime fiction. Horsley identifies certain narrative patterns and features of noir fiction and film that have infiltrated many arenas of high and popular culture, such as the use of subjective viewpoints to create unreliable narrators. These narrating figures foreground questions of interpretation and highlight the notion that no one and nothing are as they seem. Horsley focuses above all on the socio-political critique that she perceives to be at the heart of the noir thriller. For writers who adopt this narrative mode explicitly set themselves up to expose the violence, disorder, and transgression of the world that they inhabit. Drawing on the fears and anxieties of contemporary readers, hard-boiled writers from Dashiell Hammett to Walter Mosley, Didier Daeninckx, and Ian Rankin respond to the dilemmas of their times in ways that are specific to their culture and that demonstrate the responsive and highly adaptable properties of such an enduring prose form.

The increasing cultural legitimacy that the hard-boiled genre enjoys today was, however, little in evidence at the moment of its inception and its exportation to a European audience. Initially published in instalments in cheap popular magazines in America, such work was held to have very little value, its conditions of production denying it any real status. By the early I 940 , the beginning of Hollywood's film noir production promised Hammett and the hard-boiled school a degree of recognition with the release of The Maltese Falcon in I94I, scripted and directed by John Huston. Yet, all production of film noir was stopped in the same year. The authorities felt that such films presented an antisocial and unpatriotic image of the United States at a time when American GIs were being shipped abroad to fight for the greater good of just such a nation. As French film critics Borde and Chaumeton noted in their excellent I955 study of the film noir, 'il y avait antinomie évidente avec l'idéologie officielle'.

In immediate post-war France, this contestataire status was one of the prime attractions of a whole host of American literary products, perceived as resonating with new developments in post-war French fiction. In his article 'American Novelists in French Eyes', written in 1946, Jean-Paul Sartre marvels at the fact that French intellectuals admired writers such as Faulkner, Steinbeck, and Hemingway, who were so little appreciated in their own country. ${ }^{9}$ For Sartre, what such writers brought to the post-war French literary world was twofold: firstly, an understanding of an alienated humanity that suited the 'imperfections of our time', ${ }^{10}$ and secondly, innovations in style and technique with which to express such a rupture in human relations:

\footnotetext{
War was menacing us everywhere. Nevertheless analysis-analysis à la Proust, à la James-remained our only literary method, our favourite procedure. But would it take into account the brutal death of a Jew in Auschwitz, the bombardment of Madrid by the planes of Franco? Here a new literature presented its characters synthetically. It made them [characters] perform before our eyes acts which were complete in themselves, impossible to analyse, acts which it was necessary to grasp completely with all the obscure power of our souls. "

${ }^{8}$ Raymond Borde and Étienne Chaumeton, Panorama du film noir américain (Paris: Éditions de Minuit, I955), p. 35.

9 Atlantic Monthly (August 1946), I I 4-1 8.

10 Ibid., p. I 6 .

"Ibid., p. 177.
} 


\section{The American Detective Novel and the French 'Roman noir'}

Sartre credited an interwar generation of American writers with technical innovations that revolutionized the novel. For Sartre, these writers' rejection of psychological introspection (Proust and James) and their adoption of an objective style of narration meshed with a post-war Europe traumatized by the blanket bombings of the Spanish Civil War and the horrors of the concentration camps. Gone were the certainties and complacencies of the past, symbolized by the use of an omniscient narrator, able to comment on and master the course of history. Instead these novelists put in place fragmented and discontinuous narratives with characters described from the outside, denying the reader direct access to inner thoughts and lives. Two years later, in Qu'est-ce que la littérature?, Sartre would view these narrative techniques as pivotal to a reassessment of the function and working of literature. As French readers and writers became aware of their place in history and the catastrophic times in which they lived, so literature should mediate that change by reflecting the brutal unpredictability of events, only half comprehended by characters subject to forces beyond their control. From an existentialist perspective, these American literary techniques carried a metaphysical charge that chimed with the 'conscience malheureuse' of the contemporary world. ${ }^{12}$

Although Sartre makes no reference to Hammett or to other American hardboiled writers in his 1946 article, his comments were to be echoed in the work of other critics who included Hammett's work among this privileged interwar generation of American writers. The distinctions between 'high' and 'popular' American culture were more fluid in the late I940s and the notion of a school or movement of hard-boiled detective fiction was only slowly emerging. Critics understood, however, that the publication of a new wave of hard-hitting crime stories signalled a shift in the literary landscape and the coming of new fictional trends. Reactions to these American novels ranged from respect and admiration to downright hostility. These conflicting and contradictory interpretations illustrate the complex intersection of such an imported form with developments in French literature and philosophy.

Some chose to read examples of American hard-boiled fiction not as cheap entertainment but as pioneering work of great importance for French literature. Claude Edmonde Magny's L'Âge du roman américain ${ }^{13}$ is an elegant and suggestive analysis of the American novel in the light of cinematographic innovations. Magny discusses the work of Faulkner and Dos Passos but also devotes a chapter to Dashiell Hammett for his technical virtuosity. Magny's study analyses American cinema and literature as representing a humanity that no longer seeks to project a transcendental omniscient consciousness. These new American forms focus instead on the disruptions of the post-war world. Like Sartre, Magny highlights the objective narration of films and novels, where first-person narration registers the main protagonist's sense of social and metaphysical alienation. Much of this is achieved with what she terms 'an art of ellipsis', where suggestion and inference take precedence over explanation and introspection. ${ }^{\mathrm{I}}$

12 Jean-Paul Sartre, Qu'est-ce que la littérature? (Paris: Gallimard, I948), p. 294.

13 (Paris: Seuil, 1948).

14 In this context, Magny made explicit parallels between the self-alienation of Meursault in 
In her work, Magny also discusses the contribution of Dashiell Hammett to creating such a new form of writing and representation. Hammett stands out as the master of an 'esthétique du procès verbal', ${ }^{15}$ using the persona of the wisecracking private eye to allow equivocation to float over the text and blur the motivations and intentions of his character. Here there is no human essence but rather a series of assumed identities put on to face the world. In The Dain Curse (1928), for example, the Continental Op, the never named private eye, investigates the febrile world of heiress Gabrielle Leggett, who is convinced that she is cursed to bring on the death of those closest to her, including her father. In a narrative characterized by drug-induced states and the paranoia of possession and heredity madness, the Continental Op's role is not only to solve the mystery of Edgar Leggett's death but also to function as a kind of psychotherapist, able to cure Gabrielle of her delusions and to show up the real motivations of those who claim to be her friends and allies. As an investigation of the world of Gabrielle Leggett, Hammett's crime narrative leaves the reader with a troubling sense of hidden possibilities and meanings under the conventional surface of daily lives and existences.

Magny's reception of Hammett's work was to make the connection that the American hard-boiled crime novel not only had affinities with a Golden Age of interwar American writers but also had much in common with existentialist perceptions of human relations. ${ }^{16} \mathrm{~A}$ bleak tone, alienated characters, and a minimalist style in both literary traditions presented the post-war world as a trap or snare with individuals doomed to failure in their life projects and incapable of ordering events around them. Death and despair seemed to haunt the texts. However, this homology between an American hard-boiled tradition and French existentialism was not always treated in such a positive light in the late I940s. Other writers and critics adopted a very different view of the relationship between the two, expressing fears that a new American form would submerge French culture.

One of the most hostile opponents of this invasive and 'contaminating' American hard-boiled detective fiction was Thomas Narcejac. In La Fin d'un bluff, Narcejac argued that the primacy of the classic mystery text, dominant for over a century, was being eroded by a form of sensationalist and gratuitously violent writing coming from the United States. ${ }^{17}$ In these novels, death was treated as a mere commonplace to the point that victims were presented as pure objects, while the finely balanced interplay of reason and fear in the classic whodunnit was replaced by action and high emotion that appealed to readers' baser

Camus's L'Étranger and character presentation in Dos Passos. For Magny's comparison of American technique and French philosophy, see Chapter 3, 'L'ellipse au cinéma et dans le roman'.

${ }_{5}$ Magny, L'Âge du roman américain, p. $5 \mathrm{I}$.

${ }^{16}$ See Robert E. Conrath in 'Pulp Fixation: le roman noir américain et son lecteur français d'après-guerre', Revue générale (December 1995), 37-45, for a fuller investigation of the American hard-boiled detective novel and its relationship to the preoccupations of post-war French existentialism.

17 La Fin d'un bluff: essai sur le roman policier noir américain (Paris: Le Portulan, 1949). One of the ironies of Narcejac's study is that he too was writing 'fake' American hard-boiled novels at this time in tandem with Serge Arcouët (Terry Stewart). Faut que ça saigne (Paris: Éditions du Scorpion, 1948) was one of their first collaborations. 


\section{The American Detective Novel and the French 'Roman noir'}

instincts. Narcejac conceded that this obsession with the violence, strangeness, and horror of the world was of its time: 'si le roman contemporain est noir, c'est parce que l'humanité vient d'entrer dans l'âge de l'angoisse'. ${ }^{8} \mathrm{He}$ compared the works of Peter Cheyney and James Hadley Chase (the first writers in the Série noire) to Malraux, Camus, and Sartre, French writers whom he considered to have invented a penetrating and incisive form of roman noir. In contrast, he declared the roman policier noir américain to be little more than a bastardized version of French concerns. These American novelists merely mimicked the dark world vision of a new generation of French writers. In place of the philosophical and metaphysical dimensions of their writing was sexual and physical violence that bore all the hallmarks of American mass culture in its worst forms. With its crass commercialism and lack of intellectual content, the roman policier noir américain appeared to Narcejac as a dangerous and 'dumbed down' version of French innovation.

The opposing views of Magny and Narcejac point to the core dilemma for French intellectuals assessing the arrival of American hard-boiled detective fiction. Would it be an enriching literary model that fed into existing French cultural and philosophical trends, such as existentialism? Or would the American hard-boiled novel be at best a distraction and at worst a distortion of French talents and values? These early debates focused predominantly on the style and form of the hard-boiled model. Yet for those who first adopted the hard-boiled format, it was less the formal innovation that attracted them than the avenues it opened up for a trenchant and often bitter socio-political critique of the r 940 s and early I950s. For French writers like Terry Stewart and John Amila did not simply imitate the American template or produce a watered-down version of French existentialist concerns. In their hands, the early French roman noir was far more explicit than its American counterpart in its attack on certain aspects of American culture and society. In short, the American hard-boiled detective story was reconfigured to accommodate specifically French concerns over global capitalism, collective action and labour politics, and the legacy of the war years.

The most influential roman noir series in France is the Série noire, created by Marcel Duhamel in 1945. Duhamel and his series collected together what had initially been viewed as a disparate set of imported texts and gave them a collective identity for the first time. Still in existence over fifty years later, the Série noire is synonymous with a hard-boiled tradition increasingly the domain of younger French writers, like Thierry Jonquet and Didier Daeninckx. Yet in I 945 and for decades after, the roman noir in France was presented as the exclusive preserve of Americans. So much so that the first two writers in the series, Peter Cheyney and James Hadley Chase, both British, were marketed as American, while the first two French writers adopted American pseudonyms. Duhamel, an accomplished translator with connections to interwar French surrealism, set up the series as a means of disseminating an exciting new form of American writing to a voracious French readership. Although a number of such novels had been available in mainstream series in the r93os in France,

\footnotetext{
${ }^{18}$ Narcejac, La Fin d'un bluff, p. 42.
} 
the works of writers such as Raymond Chandler, Horace MacCoy, and James Cain were to reach a different readership with the Série noire. Published by Gallimard and exploiting the craze for all things American, the first Série noire novels were and still are read by both the cultured middle classes and the less educated, the classic example being Sartre's tongue-in-cheek comment in Les Mots that he preferred the Série noire to Wittgenstein. ${ }^{19}$

Duhamel's marketing of the series on the dust jackets of the early novels unashamedly exploited the tropes of a dynamic, dangerous, and sensational America, warning off readers with delicate sensibilities:

Que le lecteur non prévenu se méfie: les volumes de la Série noire ne peuvent pas être mis entre toutes les mains. L'amateur à la Sherlock Holmes n'y trouvera pas souvent son compte. L'optimisme systématique non plus. L'immoralité, admise en général dans ce genre d'ouvrages, uniquement pour servir de repoussoir à la moralité conventionnelle, y est chez elle tout autant que les beaux sentiments, voire que l'amoralité tout court. L'esprit est rarement conformiste. On y voit les policiers plus corrompus que les malfaiteurs qu'ils poursuivent. Le détective sympathique ne résout pas toujours le mystère. Parfois, il n'y pas de mystère. Et quelquefois même pas de détective du tout. Et alors? . . . Alors, il reste de l'action, de l'angoisse, de la violence - sous toutes ses formes et particulièrement les plus honnies - du tabassage et du massacre. ${ }^{2 \circ}$

From the beginning, then, it was clear that Duhamel was less concerned with rules and formulas (sometimes there would be no detective or even a mystery) than with the atmosphere, style, and dark vision of the series. What he wanted, he would claim in interviews, was the roman noir as 'un document et un témoignage sur notre époque'. ${ }^{21}$ Yet, as later critics would explain, the novels in the Série noire did more than passively reflect their times. They were often a critical engagement with the institutions and power structures that regulated Western societies. This image of the roman noir in France as a popular form of littérature engagée was the predominant theme in the 1997 issue of Les Temps modernes devoted to the roman noir. ${ }^{22}$ Guest editor Jean Pons was one among many contributors to construct a transhistorical mission for the roman noir as a narrative which investigates its times, deconstructing the real to expose hidden meanings and ambiguities. The roman noir was, he declared, 'un travail de dénonciation romanesque' ${ }^{23}$ The early novels of the first two French writers in the Série noire, Terry Stewart and John Amila, took up this contestatory role with their representations of an imagined America in the late I940s and early 1950 os.

The names of Stewart and Amila hide the identities of Serge Arcouët and Jean Meckert respectively. Between them, they published the first three French novels in the Série noire: Terry Stewart's La Mort et l'ange (1948) and La

${ }^{19}$ Jean-Paul Sartre, Les Mots (Paris: Gallimard, I964), p. 67.

${ }^{20}$ Taken from the dust jacket of Terry Stewart's La Mort et l'ange (1 948) but also reproduced extensively in literary criticism about the Série noire. See e.g. Narcejac, La Fin d'un bluff, p. 52.

${ }^{21}$ Marcel Duhamel, 'Anatomie du thriller', Les Cahiers de la pensée sauvage, I (Winter, 1984), 6-1 5 (p. 9).

${ }^{22}$ Les Temps modernes, 595 (August-October 1997), subtitled 'Pas d'orchidées pour les Temps modernes' in homage to James Hadley Chase's influential early Série noire novel Pas d'orchidées pour Miss Blandish (1946).

${ }^{23}$ Jean Pons, 'Le roman noir, littérature réelle', ibid., pp. 5-14 (p. I I). 


\section{The American Detective Novel and the French 'Roman noir'}

Belle Vie (1950), and John Amila's Y a pas de bon dieu! (1950). ${ }^{24}$ In the late I 940 s these names gave their texts a ring of authenticity as writings from and about America, even if Amila was to parody his own identity on the title page, claiming that $Y$ a pas de bon dieu! was 'traduit de l'américain par Jean Meckert'. Neither author had ever set foot in America when they wrote their novels in the late I940s, thereby constructing a purely textual projection of America based on the texts, reports, films, and souvenirs of others.

What immediately strikes the reader in all three texts is the absence of the private eye as a protagonist in the narrative. Taking Duhamel at his word, the texts work with the atmosphere, style, and world vision of the American hard-boiled detective novel rather than the detecting figure of the private eye. In La Mort et l'ange Ben Zweed, a cold-blooded and remorseless serial killer, is waiting on death row. The text charts, in flashback, how he came to be the infamous 'ange noir' as he talks with the seemingly amiable guard, Matt. In La Belle Vie the action takes place in an unnamed industrialized city not far from Pittsburgh and follows the actions of Mears Conway, President of the union of workers at a refrigeration plant, during a prolonged strike for better working conditions. In $Y$ a pas de bon dieu! the story is again told in flashback as Pastor Paul Wiseman, now in prison, recounts how the small community of Mowalla attempted to oppose the building of a dam which would flood their lands. ${ }^{25}$

In many ways, $Y$ a pas de bon dieu! and La Belle Vie have much in common, both in their representations of America and in the transposed critique they could be said to provide of post-war France. The dominant theme is what Jean-Noël Blanc calls 'la ville des pouvoirs', the city as a spatial projection of how big business, political interests, and the forces of law and order conspire to defeat the legitimate interests of workers and the ordinary man. ${ }^{26}$ The America that emerges from these texts does not promise the dawn of a new age but rather the exploitation of the masses in the name of greed and technological progress. In $Y$ a pas de bon dieu! the townspeople of Mowalla manage to unite only provisionally to oppose the dam project. The institutions that might be thought to provide support and help, the police force and organized religion in the guise of the Methodist Church, inevitably fail them in their hour of greatest need. In the end, they discover that the dam project is actually a cover for uranium mining, a scheme that would contaminate land and water for miles around.

Yet just as the community faces isolation from all quarters (they are even presented as Communist agitators in the local press), they also face internal divisions, fear, and betrayal. Their spokesperson, Pastor Wiseman, epitomizes the weaknesses of their resistance. A former Second World War soldier, he is tempted and succumbs to the advances of a young girl in the community and is swept up in the escalation of violence. As a man of God, Wiseman could

${ }^{24}$ These novels were respectively nos. 18,61 , and 53 in the series.

${ }_{25}$ According to Jean-Pierre Schweighaeuser, Mowella was in fact a transposed reference to the French village of Tignes, threatened by the building of a dam. See Schweighaeuser's article 'Du roman de voyou au roman engagé', Les Temps modernes, 595 (August-October 1997), 100-20 (p. I ro).

${ }_{26}$ Jean-Noël Blanc, Polarville: images de la ville dans le roman policier (Lyons: Presses Universitaires de Lyon, I99 I). 
be expected to represent the possibility of a redemptive narrative in the text, a sense of human compassion and forgiveness. Instead, he kills to protect himself, dehumanizing his enemies to see them as human trash: 'Il [Mikos] était à la limite de l'humain, à ce moment où la pitié n'est plus sollicitée, où l'on n'a plus devant soi un semblable, un frère de Seigneur, mais un rebut quelconque. ${ }^{27}$ No one, not even Pastor Wiseman, can claim moral superiority or greater wisdom. In this dark vision, all resistance to the forces of capitalism is doomed to failure.

In La Belle Vie, a similar set of themes and positions emerges as once again a community, this time of industrial workers, is faced with the underhand dealings of big business. Their legitimate claims for better working conditions are exploited to take even more from them, in this instance their social housing, as those with a stake in the factory and its assets wish to use this land for an upmarket housing development. The narrative opens with the murder of Noa Judd, the respected and principled spokesperson for the strikers, and the election of Mears Conway, like Wiseman a man torn between his principles and his passions. Mears represents the roman noir figure of the rebel whose initial laudable stance will degenerate into adopting the same methods as his aggressors, in this case intimidation, humiliation, and eventually murder. Stewart adds an effective class-war dimension to events as Mears is torn between his working-class loyalties and individual passions. Mears's sexual betrayal of his working-class lover, Nouk, through his liaison with Vanna, the sister of his class enemy, Ferrars, opens up the text to a pessimistic reading of the future for worker solidarity and collective action. In the last scene, as Mears and Vanna board an aeroplane for Mexico, they abandon the workers to the riot police set to evict them from their housing. The reader is left with the uncomfortable impression of betrayal at many levels, as Mears's political and social conscience is sacrificed in pursuit of an illusory personal happiness.

While Y a pas de bon dieu! and La Belle Vie target the effects of rampant capitalism, La Mort et l'ange proposes a different take on an imagined America. Set on death row, the novel can be read on one level as a first-person narrative about the life of a serial killer; from his sexual inadequacies as an adolescent to his contract killing and unconditional loyalty to a female gangster boss. Yet the context of the narration, death row, and the relationship which builds up between inmate and guard adds another dimension to a text which clearly espouses an anti-death-penalty message.

Firstly, Ben's tales of appalling horror and violence take place against the backdrop of socially sanctioned killing. With their conversation spread over a number of days, Ben and Matt's lives are regulated by a remorseless rhythm of death as each inmate's time is flagged up. These are literally 'condamnés en sursis', like Sartre's protagonists in Le Sursis, living in a state of perpetual anxiety until the inevitable moment arrives. ${ }^{28}$ Ben's impersonal narration of the atrocities he has committed finds its echo in the system that will eventually terminate his own life. Indeed, the parallel implicitly made between the individual killer and the State as killing machine is made clear when Ben ponders the experience of war:

${ }_{27}$ Amila, Y a pas de bon dieu!, p. $5^{2}$.

${ }^{28}$ I am grateful to Margaret Atack for drawing my attention to this connection. 


\section{The American Detective Novel and the French 'Roman noir'}

Tenez, il paraît qu'à la guerre on vous oblige à massacrer un tas de types qui vous ont rien fait et que vous connaissez même pas. La différence entre vous et eux, c'est que vous n'êtes pas habillé de la même couleur. Plus vous en tuez, et plus vous avez des chances d'obtenir des médailles sur votre uniforme. C'est pas idiot, des affaires pareilles? Dans la vie ordinaire, tout est différent . . . T'as tué? Bon, eh, ben mon salaud, t'es mûr pour le grille-pain et on se gênera pas pour dire à tout le monde que t'es un criminel et le dernier des salopards. ${ }^{29}$

Here, the cold-blooded serial killer points to the absurdity of a world order that rewards mass killing in wartime but condemns those who perpetrate similar acts in peacetime. Ben's own treatment highlights the hypocrisy of a victorious American nation, triumphant after a just war but which continues execution practices reminiscent of Nazi Germany.

Yet Matt's position as an increasingly sympathetic listener in the text would seem to undercut Ben's black vision of humankind. Here is one figure who, like the reader, attempts to understand Ben's life and his motivations. Yet, like Conway and Wiseman before him, Matt is another man who betrays those around him. His conversations with Ben are not as they seem. He is an undercover FBI agent writing a report on the psychology of serial killers in which Ben's story will be but one among many others. Ben's words will be manipulated to represent yet another example of futile rebellion against the system. The bleak ending of the text, as Matt and his boss discuss Ben's case, suggests that such killers are used by state institutions to learn how better to regulate, control, and police ordinary citizens.

The narrative projections of America in all three of these texts are predicated on a number of the tropes that have characterized anti-American discourses over the century. They demonstrate a fear of American technological production and the forces of rampant capitalism. They reinforce a belief that here was a country bereft of civilized values and given over to excess and violence. In the late I940s, when memories of America as the liberator of Europe from oppression were still fresh in people's minds, such a dark vision seems strangely out of step with the post-war economic boom American investment promised. Yet, these texts could be said to draw less on realistic images of America than on post-war French anxieties about the dawning of a new era. The failure of collective actions in La Belle Vie and Y a pas de bon dieu! could represent fears that the French working classes would prove unable to improve their situation, despite the promises and electoral success of French Communists and Socialists in the late I940s and early I950s. In these texts, the united forces of global capitalism, strongly connected to American economic imperialism, quell any abortive rebellion arising from a workforce divided against itself.

This deflating of triumphant post-war narratives finds its strongest expression in La Mort et l'ange, where the backdrop of the American penitentiary system provides Stewart with the means of commenting on the recent past. In his explicit paralleling of a state killing system and the individual psychotic, it is likely that Stewart was encouraging readers to connect such scenes to wartime killings and Nazi extermination policies that dehumanized and objectified whole communities. Coupling the genocidal policies of Nazi Germany

29 Stewart, La Mort et l'ange, p. 96. 
with post-war America reveals a troubling perception of America in 1948, a society already in the throes of the McCarthy witch hunts and subject to Cold War paranoia. In an increasingly polarized new world order, where was France to stand in relation to its recent saviour and what did it say about France's role on the international stage to be allied with such an ambivalent image of the American superpower?

This article began with Jean-Philippe Mathy's paradigm of discontinuity with America and France in an uneasy and shifting set of oppositional relations in the twentieth century. The French-authored roman noir of the late I940s and early I950s can be integrated into this model. For like Beauvoir in her travelogue L'Amérique au jour le jour, the early French-authored romans noirs demonstrate a strange ambivalence towards American culture, both fascinated by its innovation and modernity and repelled by its excesses and violence. Yet this is not the full story, for what became known as the roman noir developed into a powerful vehicle for French writers with a social and political conscience. The American hard-boiled detective novel was one of a number of cultural narratives adapted by French writers to represent a precarious sense of national identity at a time of growing international tensions. Early writers, like Stewart and Amila, chose to situate their first novels in an imagined America whose fantasized features threw back some disturbing images. It would not be long, however, before French writers in the Série noire chose to locate their romans noirs in a recognizable French reality, dealing explicitly with French topics, such as the conditions of the Occupation. ${ }^{30}$ This slow and hesitant appropriation of an American form for French purposes was resolutely of its time as France struggled to define itself at a time of accelerated political, economic, and cultural exchange. Reading, writing, and digesting the roman noir was part of this complex and ongoing process.

\section{CARDifF University}

Claire Gorrara

${ }^{30}$ André Piljean, Passons la monnaie (Paris: Série noire, 1951), was the first French-authored Série noire to be set in France. It was awarded the Grand Prix de la Littérature Policière in I95 I. 